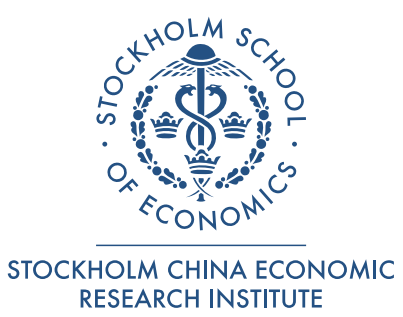

\title{
Political Change and the Business Elite in Indonesia
}

\author{
Anders C. Johansson \\ Stockholm School of Economics
}

\section{Stockholm School of Economics Asia Working Paper}

No. 34

December 2014 


\title{
Political Change and the Business Elite in Indonesia
}

\author{
Anders C. Johansson* \\ Stockholm School of Economics
}

December 2014

*E-mail: anders.johansson@hhs.se. Stockholm School of Economics, PO Box 6501, SE-113 83 Stockholm, Sweden. An abridged version of this text is forthcoming in Beja, Jr., E., Mendoza, R.U., Teehankee, J., La Viña, A., Villamejor-Mendoza, M. (eds.), Building an Inclusive Democracy. Financial support from the Ragnar Söderberg Foundation is gratefully acknowledged. 


\title{
Political Change and the Business Elite in Indonesia
}

\begin{abstract}
As Suharto's authoritarian regime came to an end in 1998, the country's business elite faced new challenges. While rent seeking had previously primarily taken place through direct relationships with and concessions from Suharto, the business elite in contemporary Indonesia operates in a setting with a higher degree of fluidity and uncertainty. This study sheds light on how the changes to the political landscape in Indonesia have affected the business elite. This is done by tracing the relationship between business and politics throughout history, from the colonial period up to contemporary Indonesia. It also discusses how these changes have made the analysis of political connections and the value of political capital more complicated and highlights some of the factors believed to be important when analyzing the economics behind business-political relationships in Indonesia.
\end{abstract}

JEL Classification: D72; G30; G38

Keywords: Indonesia; political change; rent seeking; political connections; patronage; patrimonialism; elite; oligarchy 


\section{Introduction}

Indonesia's economy has long been characterized by a small group of business elites that has controlled a significant share of country's combined wealth. During the New Order (Orde Baru), Suharto built up a complex patrimonial system, surrounding himself with a limited number of trusted business owners. ${ }^{2}$ The fact that Fisman's (2001) seminal contribution to the study of firms' political connections focuses on Indonesia is thus not very surprising. ${ }^{3}$ Fisman's analysis builds on the premise that a number of very successful Indonesian companies had, at least to a certain extent, built their fortune by exploiting benefits resulting from their close relationship to President Suharto, the country's authoritarian ruler for more than thirty years. After Suharto took power in the mid-1960s, private business began to accumulate capital and expand their operations on a larger scale for the first time. To initiate the country's era of pembangunan 4 ("development"), Suharto

2 Both the terms patrimonialism and patronage will both be used to characterize features in the Indonesian socio-political system. It should be noted that, as Mackie (2011) argues, they are two distinct but closely intertwined concepts. Patronage refers to a particular kind of mutual patron-client relationship, while patrimonialism refers to a whole socio-political system. Patrimonalism in an Indonesian setting was first used by Benedict Anderson in an influential article (Anderson, 1972), but was brought into the spotlight by Crouch in his seminal article on patrimonialism and military rule in Indonesia (Crouch, 1979).

3 See Fisman and Miguel (2008, pp 22-52) for a more detailed discussion on political connections and firms during New Order by Fisman and his colleague Edward Miguel.

${ }^{4}$ While pembangunan can mean development as in industrial or economic development, it is also associated with a much broader meaning in the Indonesian context. It was used as a way for the Suharto regime to seek legitimacy for the regime, to justify different forms of state intervention, and to rebuke 
introduced comprehensive reforms aimed at liberalizing the economy. During this period, Suharto enabled people of Chinese origin living in Indonesia to participate fully in the economy. ${ }^{5}$ An important element of this process was the mobilization of Chinese capital. Utilizing an intricate system of concessions ${ }^{6}$, Suharto began to promote business owners that had shown an aptitude for business, many of whom were of Chinese origin. Over time, the initial group of business elites, composed mainly of Sino-Indonesians, expanded and two other key groups of business elites become increasingly important. First, a growing number of pribumi (indigenous Indonesians) business owners came to exercise more influence. Second, Suharto's children became increasingly involved in a range of businessrelated activities.

While the group of business elites, some of them rightfully labeled oligarchs, expanded somewhat during the latter part of Suharto's rule, it was clear to observers that the owners of the largest business groups were related to Suharto, and that this relationship benefitted the companies under their control. This business landscape made it

opponents of the regime by arguing that they were anti-pembangunan. For more on the concept of pembangunan, see Chalmers (1997, pp. 1-5).

${ }^{5}$ In 1967, Suharto announced the Basic Policy for the Solution to the Chinese Problem. This, together with other measures, contained Suharto's approach to people of Chinese origin in the country. Instead of integration, assimilation was emphasized. For example, only one Chinese newspaper was allowed to continue operating, Chinese language schools were phased out, Chinese texts in public places were banned, and Chinese religious expressions had to be carried out privately at home.

${ }^{6}$ Important concessions included preferential access to government loans at favorable rates, monopolistic license, export quotas, rights to work with foreign businesses, forest development, and import and supply functions for government agencies. 
possible to characterize a business by its ties to the Suharto regime, as is done in Fisman's study. However, the fall of Suharto in 1998 did not only mark a change from authoritarian rule to a process of democratization, it also changed the very fabric of the country's economy. While many of the oligarchs managed to survive the Asian financial crisis and the fall of Suharto, business-political relationships were becoming more intricate and less transparent.

The aim of this study is to bridge the gap between studies by area specialists and empirically driven political economists. To do so, I will use previous research in area studies to shed light on how the changes that have taken place in Indonesia since 1998 have affected the way business and politics interact. In addition to important contributions by area specialists, the qualitative analysis builds on interviews with leading individuals in Indonesia's financial sector. The basic premise of this study is that while it is still possible (and important) to analyze and understand the value of political connections in Indonesia, the changes to the political landscape have created new challenges for such undertakings. It is therefore crucial for economists to understand these changes and how owners of large businesses in Indonesia have altered their behavior to meet those changes before a sound empirical analysis of large corporations and their political ties in contemporary Indonesia can be undertaken. As such, this study represents a first modest step towards the understanding of the quantitative effects of political connections in contemporary Indonesia. This aim differs considerably from that found in many studies by political scientists, which to varying degrees focus on the importance of the elite and/or oligarchs in the political process. 
Ford and Pepinsky (2014) provide an excellent introduction to the oligarchy and elite in Indonesia's democracy. While a detailed discussion on the role of the business elite in Indonesia's democratic process is beyond the scope of this study, it is worthwhile to address our general approach to this issue, as it influences the study of firms and political connections. Arguably the two most prominent studies on Indonesia's oligarchy are Robison and Hadiz's Reorganizing Power: The Politics of Oligarchy in the Age of Markets and Winters' Oligarchy. The two differ in the definition and analysis of Indonesia's oligarchy (Ford and Pepinsky, 2014, pp. 2-6), but share certain characteristics in their analysis of the post-Suharto business elite, for instance that old interests still dominate the political landscape in Indonesia. This study takes a similar view, but also agrees with Buehler's (2014) argument that the political landscape in Indonesia has changed significantly since 1998 and that opportunities for change are a result of "changing relations among state elites" (Buehler, 2014, p. 174). A discussion on the fluidity of elite relationships and the study of firms' political connections can be found in Section 4.2.

The rest of this study is organized as follows. Section 2 provides a detailed overview of the evolution of the entrepreneurial social class in Indonesia. It briefly discusses the colonial and early independence period before it goes into the Suharto period in more detail. Section 3 introduces the economic and political changes in 1998 and analyzes how these changes have affected the business elite. Section 4 then discusses a set of political and institutional factors that influence the behavior of the business elite in an attempt to shed further light on the issues that are important to understand when analyzing the economics of political connections in contemporary Indonesia. Finally, Section 5 concludes the study. 


\section{Business and Politics before 1998}

\subsection{The Colonial Period}

A key component in the study of the economic history of Indonesia is that an indigenous bourgeoisie never fully emerged in the country during Dutch rule (Robison 1986, p. 3). The pre-colonial political leadership came to operate simultaneously with the colonial administration, thus further dampening an already weak environment for private enterprises. The Dutch imposed a colonial bureaucracy with fixed rules, but left it to the traditional regents' class to govern the indigenous population (Houben 2002b, p. 61). This type of dual administration had an adverse effect on entrepreneurial activities. On the one hand, the Dutch took control over natural resources and extracted primary products. When the Dutch arrived in the form of the Dutch East India Company (VOC), they most likely disrupted the limited development opportunities of a weak merchant class. On the other hand, the political (and economic) role of local kings was strengthened by royal monopolies throughout the archipelago (Houben 2002a, p. 52), which further limited the role of the private sector. As the economy came to be dominated by large estate corporations (first Dutch but later also British and American), indigenous businesses remained subdued.

A merchant bourgeoisie did emerge, collecting produce from the agrarian sector, retailing imports, providing credit in rural areas, and setting up smaller manufacturing companies that focused on refining agrarian produce (Robison 1986, p. 11). However, a distinctive feature of this emerging business class was that it was dominated by people of Chinese origin. No strong landowning families similar to those in other Southeast Asian countries developed, resulting in an absence of an indigenous business class. The Chinese 
were never fully accepted into society, anti-Chinese demonstrations were not uncommon, and the Chinese were not allowed to play a public political role. As Robison points out, the marginalization of the ethnic Chinese in Indonesian society limited their ability to collude with a post-colonial state, thus further limiting the emergence of a national business class (Robison 1986, p. 29). These institutional features meant that the Dutch fully dominated the capitalist class before independence and that the Chinese dominated the local merchant class.

\section{$2.2 \quad 1949-1965$}

The evolutionary pattern of Indonesian business during 1949-1965 can be divided into two distinctive phases: an initial period during which the main policy was the attempt to build a new business class while maintaining many of the features of the colonial economic system, and second phase, initiated in late 1957, during which a much stronger focus on national state capitalism emerged (Robison, 1986, pp. 36-101). While there was a need to confront the colonial economic structure after independence, political forces realized that the colonial legacy had left the country with very little entrepreneurial activities on which to build the economy. Capital owners, including landlords and business capitalists, had failed to materialize due to the way the colonial economy was structured. As a result, it was decided that gradual capital formation was to be achieved within the existing structure of the economy. The absence of a strong indigenous bourgeoisie was also reflected in the political arena, where political struggle was primarily the concern of a small Jakarta elite (Robison 1986, p. 37). As a natural result of this reality, political leaders promoted an economic system in which foreign capital and Chinese merchants were still 
allowed to operate, at least until the emergence of indigenous capital could be achieved. Initially, the state therefore limited its involvement to control over the central banking system, public utilities, limited parts of domestic industry, and trade. Indigenous businesses were to be protected against competition from foreign and Chinese enterprises. One example of this was the so-called Benteng program, which aimed at indigenous dominance in the import sector (Booth 1998, p. 312). However, by the mid-1950s, it was obvious that the Chinese still dominated much of the economy and that the indigenous entrepreneurs were not able to make use of state protection to expand their business activities and compete with the ethnic Chinese. In the case of the Benteng program, this was especially evident as the licenses and credits handed out to indigenous firms and individuals were typically sold to importing business controlled by ethnic Chinese. The program was finally terminated in 1957. Robison (1986, p. 47) argues that state power already at this point existed at two levels, one that focused on policy and another at which patrimonial relationships between individual entrepreneurs and state officials developed.

Up until 1957, several governments had tried to get control over key sectors of the economy. These attempts had so far been ineffective. In 1957, President Sukarno introduced the so-called Guided Democracy (Demokrasi Terpimpin), a political system functioning as an authoritarian regime with the president and the military at the center of power. Later that year, what Booth $(1998$, p. 173) labels "the wholesale nationalization of Dutch interests" took place. The nationalization of most of the larger enterprises in foreign hands resulted in a very strong increase in the size of the state sector. While a sale to domestic business owners would have worked in terms of policy, it was not feasible as the pribumi businesses were typically too small, leaving a possible sale to the ethnic Chinese. 
The goal was thus to build a comprehensive national industrial policy based on state ownership of major firms (Robison, 1986, p. 80). This also suited the military, as state ownership meant possible access to these firms and their assets. While the former dominance of foreign capital was shattered as a result of this process, selected foreign business interests were still allowed to operate in the country. As the state became increasingly interventionist, with various economic and political controls, domestic firms found it more difficult to conduct their business. As a result of the policies carried out during the period of Guided Democracy, pribumi business did not advance, although SinoIndonesia enterprises were probably advancing somewhat (Robison, 1986, p. 84).

\subsection{The New Order 1965-1998}

By 1965, the Indonesian Communist Party (PKI) had become active at all levels of government. The PKI had support from Sukarno and the air force, but its advancement was at the expense of the army. A coup was attempted in September 1965 but was suppressed by General Suharto. The PKI was blamed for the coup attempt and a violent anti-communist cleansing followed, killing an estimated 500,000 people. Public opinion turned against Sukarno, and in March 1966, General Suharto obtained a presidential decree, giving him authority to maintain stability at all costs. He swiftly got rid of pro-Sukarno elements in the government and installed loyal supporters in their stead. The following year, Suharto was named acting president and Sukarno was placed in house arrest. This marked the beginning of Suharto's authoritarian regime, which came to last for over thirty years. Suharto coined the term New Order (Orde Baru) to contrast his rule with that of Sukarno and it is now commonly used for the whole period under his control. 
During the New Order, a patrimonial system developed in which strong patronclient linkages became crucial for businesses to succeed. The different kinds of firms based on ownership that existed previously still remained, but evolved into distinct corporate groups with varying features. The dominant firms can be divided into the following four groups: Sino-Indonesian enterprises, state corporations, pribumi enterprises, and Suharto family enterprises. Each of these is discussed below. ${ }^{7}$

\subsubsection{Sino-Indonesian Enterprises}

A direct result of Suharto grasping power was the increased role of the military in the economy. High-level military officials who had been in control of the finances of the military took control over a range of state corporations, including the oil company Pertamina and the state agency for logistics, Bulog (Robison and Hadiz, 2004, p. 54). Over the following two decades, military-controlled companies and foundations would expand significantly. However, while the military increased its presence and influence in the economy, it was never able to efficiently develop the capital assets under its control. To do so, the military needed a helping hand and only one group was able to provide it: the Chinese business community. Having dominated the domestic commercial distribution system during the colonial and Sukarno periods, they constituted the only entrepreneurs able to generate the profits needed for the extra budgetary funds requested by the military and different political factions (Robison and Hadiz, 2004, p. 55). Senior military officers thus typically teamed up with Sino-Indonesian business owners. While the military officers

${ }^{7}$ For a comprehensive discussion on the business sector during the early period of New Order, see Robison (1986). MacIntyre (1991) also provides a detailed analysis of the evolution of Indonesian business groups and the policy-making process during New Order. 
would provide a range of licenses, contracts and access to bank credit, the Sino-Indonesian partners provided capital and business know-how to the joint venture. These SinoIndonesian businessmen, commonly called cukong ("financial backer"), typically avoided becoming public figures.

Over time, the military ownership in these joint ventures shrank and the influence of the Sino-Indonesian counterpart increased. Some of the most important parts of the economy that Chinese business empires came to control included the import and distribution sectors, where they obtained monopolies in a range of commodities including rice and sugar, the forestry sector, and the automobile sector, where they teamed up with Japanese producers (Robison and Hadiz, 2004, p. 55-56). It is noteworthy that all of the large conglomerates discussed here emerged during the New Order period. In contrast to many Sino-Indonesian business empires in Malaysia and Thailand, none of the Indonesian conglomerates were built on old family wealth (Mackie, 2003, p. 110). Instead, it was the institutional setting that evolved during Suharto's regime that allowed these businessmen to expand their operations at a rapid pace.

While a detailed discussion on the list of the most successful Sino-Indonesian businessmen during this period is outside the scope of this study, it is useful to look closer at one example, namely Liem Sioe Leong, the owner of the Salim Group and the most successful Sino-Indonesian businessman during the New Order period. Liem had come close to Suharto during the 1950s. At the time, Liem was supplying a range of goods to the army (Borsuk and Chng, 2014, p. 61). As soon as Suharto took power, Liem started receiving preferential treatment in the form of various licenses and state contracts. Two of his most lucrative businesses were the import of clove (an important component in 
Indonesian kretek cigarettes) and his milling company P.T. Bogasari, for which he received a state license to supply the whole of western Indonesia with flour (Eklöf, 2002, p. 217). In the mid-1980s, the Salim Group had become the largest conglomerate in the country, with hundreds of subsidiary operations in a wide range of sectors.

Hill (1996, p. 113) provides a detailed table of the largest Indonesian conglomerates in the early 1990s. Of the 25 largest conglomerates, only four were controlled by pribumi owners. Perhaps even more tellingly, the seven largest conglomerates were all controlled by Sino-Indonesian entrepreneurs. ${ }^{8}$ Similarly, Eklöf (2002, p. 223) notes that 18 of the 20 largest conglomerates and $80 \%$ of the companies listed on the Jakarta stock exchanges were controlled by Sino-Indonesian businessmen in 1993. In the list of the largest conglomerates in the early 1990s, the Salim Group was clearly the dominant player, with a turnover more than triple that of the second largest conglomerate at the time.

\subsubsection{State Enterprises}

Even though Indonesia was one of the developing countries that introduced liberal economic reforms early on, it was never fully committed to creating a liberalized economy. Instead, the reforms were mainly meant to promote an import-substitution growth strategy and to attract foreign capital (Eklöf, 2002, p. 219). While the Indonesian government introduced relatively comprehensive tax, trade and financial reforms in the

\footnotetext{
${ }^{8}$ These seven conglomerates were: Salim, controlled by Liem Sioe Liong; Astra, controlled by Prasetia Mulya Group; Lippo, controlled by Mochtar Riady; Sinar Mas, controlled by Eka Tjipta Widjaya; Gudang Garam, controlled by Rachman Halim; Bob Hasan's conglomerate; Barito Pacific, controlled by Prajogo Pangestu.
} 
late 1980s, the state corporate sector never underwent the same reform process. This meant that while privatization was gaining momentum in many other countries around the world, many of the larger corporations in Indonesia remained under state control. As noted by Hill (1996, p. 103), there were a number of underlying reasons for the hesitation to introduce a comprehensive privatization program. First, socialist ideas going back to the independence days were still strong among the Indonesian leadership. Second, there was a general distrust towards the capital markets, which were needed if the privatization process was to be successful. Third, there was a strong desire among those in leading positions to promote pribumi business, and the state sector was seen as an important instrument for doing so. Were the state enterprises to be privatized, they would no doubt come under the influence of foreign interests and the Sino-Indonesian businesses, which had access to much more capital than their pribumi counterparts.

While privatization was not a leading theme in the state corporate sector during the New Order, the abysmal performance of state enterprises forced policy makers to take a closer look at the management of these corporations. As a result, a number of state enterprises were handed back to their original owners in 1967, and most state controlled corporations were established as limited liability companies two years later (Hill, p. 1996, p. 103). Throughout most of the 1970 s and the early 1980s, the state corporate sector became the focus of import substitution and a general ambition to reach self-reliance in a range of sectors. The concept of "national resilience" and strategic autonomy became important (Robison, 1988). One of the key proponents of strategic autonomy was Bacharuddin Jusuf Habibie, at the time minister of research and technology. He was close to Suharto and his influence in the state corporate sector increased after ten of the largest 
state enterprises were placed under his control through the establishment of the Strategic Industries Management Board (Badan Pengelola Industri Strategis, BPIS). After problems with many of the state-owned companies during the 1970s, notably with Pertamina that faced severe financial difficulties in 1975, a new comprehensive overview of the state corporate sector took place in the mid-1980s. Nevertheless, the state enterprises continued to perform poorly. One of the reasons for this was most likely the fact that the enterprises were used for a number of different purposes as discussed earlier. Moreover, it is well known that companies controlled by the state typically have objectives beyond profit maximization in most countries and that they are, in general, outperformed by privately controlled firms. ${ }^{9}$

\subsubsection{Pribumi Enterprises}

As noted earlier, an indigenous bourgeoisie was slow to emerge after independence in Indonesia. Pro-pribumi policies such as the Benteng program did not alter the business sector dramatically. The nationalization process in 1957 did provide a change, as it allowed pribumi to access capital, now in the form of state capital. A pribumi capitalist class thus started to emerge in the 1950s and 1960s. As Suharto seized power, many of the leading pribumi entrepreneurs experienced deterioration in their businesses, especially those who had been close to Sukarno. Several of those with close ties to Sukarno had their

\footnotetext{
${ }^{9}$ For example, a large number of studies on state enterprises in China highlight what is commonly
} called the policy burden, i.e. the fact that state-controlled companies have to certain state objectives in addition to profit maximization (e.g. Lin et al., 1998; Lin and Tan, 1999; Johansson and Feng, 2013). For more details on performance among state- and privately controlled firms, see D’Souza and Megginson (1999) and Megginson and Netter (2001). 
assets confiscated and many others were active in sectors that now came under pressure, including the import and distribution of cars and machinery (Robison, 1986, p. 330).

The early period of the New Order saw the emergence of a number of new pribumi business groups, typically around families of high-level politico-bureaucrats and military officials (Eklöf, 2002, p. 221). The most striking example is Ibnu Sutowo, who at the time was the head of the state-controlled oil company Pertamina. During the decades following Suharto's rise to power, Sutowo built the largest pribumi business group in the country (Robison, 1986, p. 350). Sutowo's own wealth started to decline in the 1970s but a number of pribumi entrepreneurs who had built their businesses under his patronage, such as Fahmi Idris, Siswono Judo Husodo, and Guntur, continued to expand their operations (Eklöf, 2002, p. 221).

As resentment towards the dominant Sino-Indonesian influence in the domestic economy grew and as support from sections within the military declined in the 1980s, Suharto began to widen his support base by courting the Muslim (pribumi) middle class. In addition to growing discontent with the Sino-Indonesian economic dominance, growing dissatisfaction in the military centered on favoritism and the influence of Suharto's children and other family members, as well as the military's waning political and economic power resulting from the growing influence of the president and a select number of leading politico-bureaucratic families (Eklöf, 2002, p. 224). Through initiatives such as the establishment of ICMI, Suharto hoped to secure support from the pribumi middle class and business leaders. This development also meant that pribumi economic interests increased during this period. Pribumi business leaders started to exert increasing influence through two main vehicles; Himpunan Pengusaha Muda Indonesia (HIPMI), the Association of 
Young Businessmen, and Kamar Dagang dan Industri (Kadin), the Chamber of Commerce and Industry. Over time, pribumi entrepreneurs expanded their business interests by building alliances with existing conglomerates and politico-bureaucrat families. In addition to these business-focused relationships, they also built important political alliances with Golkar, the ruling party during most of the New Order period, and Sekretariat Negara (Sekneg), the State Secretariat, and thus came to play an important role in both the economy and in politics. Examples of such successful pribumi business owners include Aburizal Bakrie, Siswono Judohusodo, Fadel Muhammad, and Ponco Sutowo (Robison and Hadiz, 2004, p. 133).

While the term pribumi business owners is used here primarily to define a homogenous group of businessmen based on their ethnicity, the group is composed of individuals owning a variety of businesses in terms of size and economic importance. Winters (1996, pp. 42-43) points out that pribumi businessmen during the early period of the New Order were primarily small- and medium size entrepreneurs that continuously pressed for state policies that would provide benefits that the markets typically would not. However, as noted earlier, a small number of pribumi business owners had managed to expand their businesses and build up larger conglomerates similar to the leading SinoIndonesian businessmen. As a result, around the end of the oil boom in the early 1980s, pribumi businesses had become more diverse, with a small number of economically and politically very important players.

\subsubsection{Suharto Family Enterprises}

While per definition constituting a part of the pribumi business sector, it is useful to separate the businesses controlled by members of the Suharto family into a group of 
their own. This is not least because many observers believe that the expansion of the business interests of Suharto's children would come to play a role in his downfall.

Members of Suharto's family had been active in business since the beginning of the New Order. For example, Suharto's nephew Sudwikatmono's company (supported by Liem Sioe Liong) obtained a monopolistic investment license and received loans directly from the central bank in 1969; and Bernard Ibnu Hardjojo, brother of Suharto's wife Siti Hartina Suharto, obtained an investment license in the cement industry in 1971 (Sato, 2003). However, although the Suharto family was active in business activities early on, it was not until the 1980s, when his children started to expand their business interests, that the family dramatically increased its direct involvement in the economy in the form of business ownership. In the 1990s, the family controlled many of the pribumi conglomerates that were large enough to match the leading Sino-Indonesian conglomerates. For example, of the 30 largest business groups, four were controlled by pribumi, and out of these four, three were controlled directly by the Suharto family: Bimantara, which was the largest pribumi business group in the mid-1990s, was headed by Bambang, Suharto's second son; Nusamba was owned by a yayasan (foundation) controlled by Suharto; and Humpuss was controlled by Tommy, Suharto's third son (Sato, 2003). Moreover, by the mid-1990s, several of Suharto's family members occupied important positions in Golkar, where they further expanded their political influence. One result of the increased business activities of members of the Suharto family and their close relationships with leading Sino-Indonesian business owners was that an increasing number of pribumi entrepreneurs were unable to maintain easy access to patronage (Fukuoka, 2012a). This development would come to play a role in the process that led to Suharto's fall in 1998. Winters notes that as Suharto's 
children expanded their business interests in a rapid pace, "the result was a loss of equilibrium as the frictions from a new and seemingly unstoppable pattern of predation and threats increased to levels never before reached during the New Order" (Winters, 2011, p. 166). While Suharto defended his children's right to be in business and claimed that they helped correct the Chinese-pribumi imbalance, a majority of the pribumi business community felt that they were hurting the pribumi cause as they allowed Suharto to sidestep demands from leading pribumi businessmen to be put on par with the leading Chinese cronies (Schwarz, 2004, pp. 146-147).

Towards the end of the New Order, in addition to increasingly dominating most aspects of political life, members of the Suharto family had accumulated a significant amount of wealth. In an investigative report on the family, Colmey and Liebhold (1999) identified some of this wealth. Besides several billions of US dollars in foreign bank accounts and a vast range of luxury items, Suharto and his children controlled approximately 3.6 million hectares of real estate. Suharto's six children had equity in at least 564 different Indonesian companies in addition to hundreds of overseas companies. Except for the two youngest daughters' relatively modest wealth of approximately 30 and 75 million US dollars, respectively, the estimated wealth for each of the remaining five children ranged from 700 million to 3 billion US dollars.

While the Suharto family business expanded considerably as Suharto's children grew up, the size of the family empire is difficult to pin down. Using a data sample of close to 3,000 of the publically traded companies in East Asia, Cleassens et al. (1999a) estimate that $16.6 \%$ of the total market capitalization in Indonesia could be traced to the ultimate control of the Suharto family towards the end of the New Order. In their data sample, they 
also find that Suharto family members controlled assets worth 24 billion US dollars, and constituted the largest stockholder in Indonesia at the time (Claessens et al., 1999b). Brown (2006), on the other hand, argues that the business empire under direct control by Suharto's closest family was "comparatively small" and that it was marked by internal competition among companies such as Bimantara Citra and Humpuss towards the end of the Suharto regime. However, Brown's estimations (they remain just that as her analysis focuses on only three of the corporations within the Suharto business sphere) aside, its rent-seeking activities were significant. In addition, Suharto family members' increasing role in politics destabilized the political landscape and undermined the alliance between Suharto and important members of the elite.

\section{Crisis, Transition and the Business Elite}

The financial crisis that shook East and Southeast Asia in 1997-1998 had farreaching economic and political implications for Indonesia. This period also marks the shift from a patrimonial system, with a selected few extremely prominent businessmen around Suharto, to an evolving democratic process in which former and upcoming members of the business elite had to reposition themselves. To shed light on the role of the business elite in the events that marked and to great extent triggered this change, this section first describes the evolution of the financial crisis and then discusses the political crisis that followed in its footsteps and how the business elite responded during this time of crisis. 


\subsection{The Financial Crisis}

When the financial crisis in Thailand broke out during the first half of 1997, most observers did not foresee a contagious effect in the region. ${ }^{10}$ As the Thai baht came under increasing pressure, the Thai government was finally forced to float the currency. The baht depreciated rapidly and the country's already high debt levels became increasingly difficult to sustain due to the fact that a significant portion of the debt in primarily the corporate sector was denominated in foreign currency. The crisis soon spread to many of Thailand's neighbors. Indonesia, together with Thailand and South Korea, were hit the hardest, although several countries in the region were negatively affected by the crisis, notably Malaysia, the Philippines, Hong Kong, and Laos. In Indonesia, as in several of its neighboring countries, the crisis took the form of a "twin crisis", a term used for situations characterized by a currency crisis combined with a crisis in the domestic banking sector. ${ }^{11}$

When Thailand's central bank let the Thai baht float on July 2, 1997, other currencies in the region came under increasing pressure. The Indonesian rupiah was among the hardest hit, making it increasingly difficult for Bank Indonesia to defend its peg to the US dollar. On August 14, 1997, the rupiah was set to float and the currency plunged

${ }^{10}$ In fact, most of the economies in the region, Indonesia included, were widely regarded to be in good shape at the time. For analyses, comparative studies, and (often at least to some extent conflicting) discussions on the Asian financial crisis, see, e.g., Goldstein (1998); Krugman (1998); Radelet and Sachs (1998); Kaminsky and Reinhart (1998, 1999); Corsetti et al. (1999); Mishkin (1999); Johnson et al. (2000).

11 The term twin crisis was first discussed in length by Kaminsky and Reinhart (1999), who in their analysis of a series of financial crises argued that currency crises are often preceded by problems in the banking sector. The currency crisis then amplifies the problems in the banking sector, and a vicious spiral ensues. 
dramatically. By early October, the rupiah had depreciated more than $30 \%$, prompting the Indonesian government to ask the International Monetary Fund (IMF) and the World Bank for help. On October 31 , the IMF agreed to a rescue package amounting to US\$43 billion, conditional on the Indonesian government closing down 16 insolvent banks and the introduction of a comprehensive reform program. ${ }^{12}$ The closing of the insolvent banks was meant to restore confidence in the Indonesian banking system and to signal that the government would be serious in its effort to implement prudential regulatory measures (Cole and Slade, 1998).

On January 8, 1998, Suharto presented his state budget plan. Most observers realized that the budget was completely unrealistic and that it was not complying with the reform program that the Indonesian government had agreed to implement as part of the loan package provided by the IMF. As a result, the rupiah plunged to an all-time low. ${ }^{13} \mathrm{At}$ this point, Suharto was pressured to postpone a large number of projects subsidized by the government in an effort to cut government expenditures and reduce the reliance on foreign debt. The same week, Indonesia experienced a wave of panic buying as food staples increased in price following the fall of the rupiah. The following week, Suharto signed a

12 The focus on reforms following the traditional Washington Consensus was criticized early on. For example, Joseph Stiglitz, at that point chief economist of the World Bank, questions both the assumptions and effects of the measures in a speech on January 7, 1998. Similarly, Jeffrey Sachs, then Director of the Harvard Institute of International Development, was a strong critic of the IMF's approach, arguing that the crisis in the Asian countries differed significantly from previous crises that the IMF had worked to solve. For details on the measures in the real sector of the economy, see Soesastro and Basri (1998).

13 On January 22, 1998, the rupiah feel to a record low of 17,000 to the US dollar. This represented a decrease in value of more than $80 \%$ since the rupiah was floated the year before. 
new loan agreement with the IMF in which he agreed to scrap monopolies and state subsidies. However, the implementation of the new reforms did not materialize. On March 9,1998 , the IMF declared that it would delay an installment of the loan package as a result of Suharto's unwillingness to reform. A few days later, Suharto was once again sworn in as president of Indonesia. A third agreement with the IMF was reached on April 8 in which the IMF allowed subsidies to food and fuel to remain and Suharto promised to close additional insolvent banks. In May, student demonstrations were held across the country, accusing the Suharto government for failed economic policies and demanding comprehensive political reforms. Suharto tried to push back, but increasing resistance from both students and former parliamentary allies forced him to resign on May 21, 1998. At this time, vice president Habibie succeeded him as president. Suharto's 32 year reign was over.

\subsection{The Political Crisis - Sultanistic Tendencies, Student Protests and Riots}

While patrimonial features had been a key component of the Indonesian state for several decades, these features were altered in the 1990s. As noted in Section 3.3.4, one of the primary changes to the patronage system during this period was the increasing role of Suharto's children and other family members and their (primarily Sino-Indonesian) cronies. As the importance of Kadin grew, its members became increasingly vocal in their dissatisfaction with what they felt was a continued and increasing marginalization of the pribumi business class. For example, Kadin published a report in 1993, arguing that predatory Sino-Indonesian businesses were dominating the economy and, assisted by corrupt officials, pushing back smaller pribumi businesses (Fukuoka, 2012b). To further their cause, leading pribumi business owners and organizations also called for legislation 
similar to that of Malaysia's New Economic Policy, which would provide a legal basis for the preferential treatment of pribumi businesses (Robison and Hadiz, 2004, p. 132). The view of many leading pribumi business elites was thus that the patronage system had evolved into a system that heavily discriminated against pribumi-owned business activities and that this was the main reason behind the Sino-Indonesian dominance in the Indonesian economy (Schwartz, 2004, pp. 123-125). It is commonly argued that the anti-Chinese sentiments among pribumi was hijacked by the more successful pribumi business owners, supposedly in an effort to replace the strong Sino-Indonesian business elite in the patrimonial system that evolved under Suharto (e.g. Robison and Hadiz, 2004, p. 132).

As discussed earlier, while firms owned by Sino-Indonesians were very prominent during the New Order, conglomerates controlled by pribumi also expanded as a result of Suharto's patronage. For example, Aburizal Bakrie had close ties to Suharto and, similar to a number of Sino-Indonesian business owners, developed a patron-client relationship with Suharto (Hicks, 2012). However, the overall direction of the regime was towards increased power concentration. Aspinall (2005, p. 4) argues that the Suharto regime was undergoing a process of "sultanization" 14 in the 1990s, in which Suharto, his family and the closest members of his inner circle were becoming increasingly dominant. Fukuoka (2013) concurs with this, arguing that the Suharto regime "displayed strong 'sultanistic

14 Typical features of regimes with sultanistic tendencies are that they are based on personal ideology and personal favors to maintain the autocratic ruler in power. The presence of the ruler can be seen as extreme. Examples of sultanism include the Philippines under Marcos, Cuba under Batista, and Haiti under Duvaliers (Chehabi and Linz, 1998; Dominguez, 1998; Nicholls, 1998; Thompson, 1998). Several Indonesia scholars have labeled Suharto's regime as one with sultanistic tendencies. For example, Winters (2011) defines the New Order regime as a sultanistic oligarchy. 
tendencies'”. Having relied on politico-bureaucratic technocrats to oversee the economy, the increasing dominance of the family and closest allies also resulted in a breakdown in efficient policy making. For example, the closing of 16 banks in an effort to restore confidence instead lead to an open confrontation between the Suharto family and the minister of finance and the governor of the central bank. The central bank became leaderless as its governor and managing directors were repeatedly dismissed by Suharto, most likely for closing banks that belonged to his family members (Cole and Slade, 1998). Cole and Slade (1998) argue that this conflict resulted in a significant loss in the effectiveness of the technocratic ministers. Thus, having successfully relied on strong technocrats to implement needed policies in the past, Suharto's sultanization of power had resulted in him distancing himself from his policy advisors when he needed them the most.

This process coincided with increased opposition among common Indonesians to the IMF-imposed policies and what they perceived as rampant corruption in the political system. On January 13, 1998, students rallied in Jakarta to protest against the policies imposed by the IMF. As a result of the measures taken during that spring, new student demonstrations were held around the country in early May. The students felt that the steep increases in fuel and energy prices punished ordinary Indonesians and demanded comprehensive political reforms in light of what they perceived as failed economic reforms. On May 12, 1998, troops fired into a peaceful protest of approximately 6000 students at Trisakti University in Jakarta, resulting in six deaths (Schwarz, 2004, p. 355). A week earlier, students had protested in Medan after the announcement that the price of gasoline would increase by $70 \%$. Tension between students and police ensued and riots followed. Following the student protests in Jakarta, more riots broke out in many of the larger cities 
in the country. Triggered by economic problems such as food shortages, drastic price increases, and high unemployment numbers, the key targets of the riots and the looting that ensued were the ethnic Chinese. ${ }^{15}$ On May 19, Suharto tried to calm down student protests by promising early elections. However, the students rejected his proposal and a growing number of Suharto's key allies began to call for his resignation. On May 21, Suharto was forced to step down and was immediately replaced by vice president Habibie.

\subsection{The Crisis and the Business Elite}

As the economic crisis evolved, it became clear that the business elite were losing confidence in the institutional setting and the state's ability to weather the storm. It has been argued that the crisis in Indonesia differed from those in countries such as Thailand and Malaysia in terms of the origins of the pressure on the exchange rate. As put forward by Johnson (1998), key players in the financial sector in Indonesia stated that the collapse of the rupiah to a significant extent was triggered by domestic capital flight, and that foreign investors followed suit later on. That is, wealthy Indonesians moved their money abroad, thus displaying a lack of confidence in the Indonesian economy. The initial capital flight was followed by an exodus of ethnic Chinese, many of whom were prominent business leaders. As mentioned earlier, the riots during the spring of 1998 had targeted ethnic Chinese and their businesses. A direct effect of this was that affluent Sino-

15 It has been alleged that the military not only remained passive during the riots, but that it was actually involved in the riot. It was reported that organizers of the riots had characteristics similar to that of members of the military (Purdey, 2006, p. 101), and that Prabowo Subianto was one of the main figures in the military involvement during the riots in Jakarta (The Jakarta Post, 2004; Schwarz, 2004, p. 345). Prabowo was Suharto's former son-in-law and, at the time, the Army's Strategic Reserve Command (Kostrad) chief. 
Indonesians left the country in large numbers. It is estimated that somewhere between 50,000 and 150,000 Sino-Indonesians fled the country after the riots in May 1998 (Pepinsky, 2009, p. 183). Indonesian media reported that this exodus resulted in a breakdown of the logistical system, which in turn led to price increases and scarcity of goods around the country. Eklöf (2002, p. 232) argues that this was not the case. Instead, he argues that the event coincided with the continued depreciation of the rupiah, which had an adverse effect on prices of imported goods. Regardless of whether the flight of ethnic Chinese only coincided with or caused the problems in the domestic logistic system, it represented a new opportunity for pribumi businesses. Aburizal Bakrie, head of the largest conglomerate owned by a pribumi and the chairman of Kadin at the time, said that the breakdown of the domestic distribution represented a golden opportunity for members of Kadin and HIPMI (Eklöf, 2002, p. 232).

The bank restructuring program was also influenced by personal interests. For example, shortly after Suharto stepped down, Bakrie suggested that four banks, among them Liem Sioe Liong's Bank Central Asia (BCA), were to be nationalized and sold in an offering in which preference was to be given pribumi investors. The restructuring process was not completely hijacked, but many influential pribumi businessmen, including Bakri himself, Adi Sasono, and the chairman of HIPMI Hariyadi B. Sukamdani, called for redistribution of the assets with preferential treatment given to pribumi (Eklöf, 2002, p. 236). The ethnic dimension of the struggle among business elites continued to play a significant role after the crisis. For example, in 2004, Bakrie beat regional IMF head Sri Mulyani to become the Minister of Economics. Bakrie, together with Vice President Yusuf Kalla, represented an influential group of politicians with a background as owners of large 
businesses. They both supported the idea of adopting different wealth distribution programs based on ethnicity similar to what was and is implemented in Malaysia (Chua, 2009, p. 221)

Overall, the financial crisis seems to have presented a perfect opportunity for a number of leading pribumi business owners to deal with the growing dominance of the Suharto family and its close business allies, most of whom were of Chinese origin. Arguably the most active and outspoken pribumi business owner at the time was Aburizal Bakrie. His call for rebalancing wealth in favor of indigenous Indonesians was naturally also a way for him to expand his own business empire at the expense of his Sino-Indonesian competitors. But it was not only Bakrie who raised his voice to promote pribumi business interests during this period. As Fukuoka (2012b) notes, leading pribumi business owners such as Fahmi Idris, Jusuf Kalla, Fadel Muhammad, Syarif Tando, and MS Hidayat came out supporting the growing opposition movement. In the same vein, Arifin Panigoro, founder of Medco Group, voiced his support for Amien Reis, then leader of Muhammadiyah (one of the country's leading Islamic organization), an influential public person, and the first public figure in the mainstream that challenged Suharto publicly (Schwarz, 2004, p 348).

Many of the members of the Indonesian business elite turned against Suharto in 1997-1998. However, as has been discussed here, it is important to note that the main reason for doing so was the increase in what can be labeled "sultanistic tendencies" during the last decade of Suharto's reign. As his family members expanded their economic interests, and as Suharto started to groom his descendants to succeed him, an increasing number of members in the business and political elite began to look for possible change. The economic crisis provided this opportunity. As Winters (2013) aptly puts it, "they 
[Indonesia's elites and oligarchs] quietly but actively abandoned him as he faced what would be the final economic shock of his reign."

\section{Analyzing Business and Politics Relations in Contemporary Indonesia}

So why is it important for economists who want to analyze political connections in democratized Indonesia to understand the emergence of the business elite under New Order and their role in the changes that took place in 1997-1998? The answer to this is that the political transition initiated towards the end of Suharto's rule did not result in an end of oligarchs and the rest of the old business elite. As we have seen, area specialists argue that it was actually elements in the oligarchy surrounding Suharto that were instrumental in his fall from power. For example, Robison and Hadiz have stated that elements in the regime elite around Suharto felt that they needed to reorganize themselves in a new and different regime (Robison and Hadiz, 2004, p. 166). That is, Suharto had become redundant to their needs. As Fukuoka (2012a) puts it, "democratization enabled the repositioning of a variety of interests, incubated and entrenched during Suharto's long rule, within a new democratic political framework, preserving the illiberal nature of Indonesian politics."

In light of this, the changes after the New Order are not characterized by the disappearance of the dominant business elite, but rather its repositioning in the new political reality. This is of crucial importance for observers of political connections in contemporary Indonesia. While early studies on political connections and the business elite in Indonesia, such as that of Fisman (2001), focused solely on business owners' closeness to Suharto, economists now have to understand a more complex reality, which on the one 
hand is characterized by substantial remnants from the Suharto period but on the other hand has new and unique features, including continuous positioning for political power by members of the old elite, and the emergence of new business elites that develop their own ties with the politico-bureaucratic strata. As Eklöf (2002, p. 243) argues, the demise of Suharto did result in personnel changes in the political system as well as alterations of the rules of the game, with an increasing intra-elite competition for economic and political power as a defining characteristic, but the ties between business and politics does not seem to have weakened during the political transition

Before moving forward, it should be noted that a number of observers have attributed the political transition to the economic crisis that shook the country at the time. ${ }^{16}$ Others have focused on the emergence of a civil society as a cause behind democratization. However, it is more likely that, as Aspinall $(2004$, p. 83) points out, while civil society did play some a role in eroding the ideological foundations of Suharto's authoritarian rule, it was processes inside the state and the external shock that resulted in the transition. Fukuoka (2012a) puts forward a detailed argument for why civil society is insufficient in explaining the push towards democratization. Overall, it seems likely that the economic crisis acted as a trigger for both political change and the slow emergence of a civil society. It is also likely that the inherent features of the patrimonial system and the centralization of power to an increasingly smaller circle around Suharto's family, i.e. sultanization, have acted as an endogenous factor that was put in play by an exogenous shock. This is also largely in line with Pepinsky (2009), who analyzes and compares Indonesia's and Malaysia's authoritarian regimes at the time of the Asian financial crisis.

\footnotetext{
16 See Fukuoka (2012a) for a detailed discussion on reasons behind Suharto's fall.
} 
Pepinsky focuses on how the needs of owners of mobile and fixed capital are met. As mentioned earlier, it seems that it was capital owned by the Indonesian business elite that first poured out of the country, suggesting that domestic capital owners were indeed the ones that first lost faith in the system.

The rest of this section will focus on a series of distinguishing features that have the potential to significantly affect how we analyze the quantitative effects of political patronage in contemporary Indonesia. While we do not claim this list to be complete, it includes many of the important drivers behind the changes in business-political relationships since 1998. Each of these factors is characterized by a significant political or institutional change after the New Order and each of them imply a need to analyze the economic effects of political connections in contemporary Indonesia from several different angles.

\subsection{Business Enters and Dominates Politics}

The role of business associations has changed since the fall of the New Order regime in 1998. While organizations such as Kadin played a role in the policymaking process, they basically just rubber stamped business-related policies (Justiniarto, 2011, p 37). As the political landscape changed after 1998, Kadin could redefine its position and become more influential by participating in policymaking processes (The Jakarta Post, November 7, 2009). As a result, business during the post-Suharto period has become increasingly involved in politics.

While organizations such as Kadin have provided one way to influence politics in Indonesia, the business elite has also become directly involved in the political process to a 
much higher degree than during Suharto's reign. Arguably the most important expressions of Anti-Suharto feelings starting in 1998 was Reformasi (reform), which became the theme under which reformers united towards the end and after the fall of the New Order. ${ }^{17}$ Many of those who rallied under Reformasi were political liberals who wanted to play an active role in the reconstruction of the political process. Individual rights and democracy based on traditional liberal principles were key elements in this process and it was strongly supported by a group of international organizations such as the IMF and the World Bank. However, while the spirit of reform and liberal democracy during Reformasi had a significant impact in the initial stage of democratization, the movement later weakened and became primarily a series of activities carried out by students (Hadiz and Robison, 2013). A lack of organization left the modest liberal intelligentsia weak and uncoordinated. Hadiz and Robison (2013) also argues that the presidency of Megawati Sukarnoputri (daughter of Indonesia's first president Sukarno), while representing hope for a new political era for a large part of the population, became defined by failed policies and shady alliances with the military and businesses. As a result, the political arena, including the political parties, was increasingly regarded as highly corrupted.

Winters (2013) argues that oligarchs who functioned in a patron-client relationship during the New Order soon came to dominate the democratic process and gained increasing political control after the fall of Suharto. During the New Order, the business elites were to a large extent separated from the political arena. After Suharto, no

${ }^{17}$ For a detailed overview of the fall of Suharto and the ensuing period of Reformasi, see O’Rourke (2003). Also, for a somewhat more detailed discussion on the actual length of the Reformasi period, see Pepinsky (2012). 
such limitations exist. Similarly, Fukuoka (2012b) notes that one result of the changes in 1998 is that the business elite's traditional dependence on politico-bureaucrats for access to state resources is no longer necessary, as the business elite now has direct access to those resources.

One important feature in the political system is the almost complete deregulation of political funding. The lack of a functioning system for political party funding and rapidly increasing campaign costs has resulted in parties becoming increasingly dependent on financial donations (Mietzner, 2013, p. 239). One natural result of this is the concentration of political power. ${ }^{18}$ The fact that funding is crucial for the campaign process is one important reason for why the business elite has come to play an increasingly important role in Indonesian politics; as noted by Mietzner (2013, p. 95), "parties have become increasingly infiltrated by "economic society"'. Other scholars agree with the view that the political reality in Indonesia is that money for campaigning is crucial, and that only a limited number of wealthy candidates (or candidates backed by wealthy individuals) have the financial resources to run a full campaign (Buehler, 2010, pp. 273-275; Hadiz, 2010, p. 113; Winters, 2011, p. 190).

Before moving on, it is perhaps justified to raise the question of whether all business owners who get involved in politics do so because of pure monetary self-interest.

18 The importance of political competition has been researched extensively by political economists, including its effects on government size (Rogers and Rogers, 2000), the use of clientelism (Weitz-Shapiro, 2008), political selection (Galasso and Nannicini, 2011), democratic accountability (Jones, 2013), and economic growth (e.g. Bueno de Mesquita et al., 2001; Besley et al., 2010). For a detailed analysis and discussion on political competition, see Persson and Tabellini (2000). 
Mietzner (2013, p. 96) argues that this is not at all the case in Indonesia. He suggests that there are at least six different reasons for why entrepreneurs may be entering into politics: to obtain preferential treatment for the companies they own; for vanity; politicians owning businesses in order to advance in their political career; small-scale opportunists; senior party leaders receiving money from business owners; and private sector representatives advocating economic reforms. While we do agree that the final goal may differ somewhat, we adhere to the basic principles of public choice theory, arguing that the outcome they are seeking is typically based on self-interest. For example, politicians owning businesses to advance their careers would per definition improve their career outlook by engaging in rent-seeking activities. Private sector representatives that advocate economic reforms are typically doing so out of self-interest. And so on. Thus, and in line with the literature on political connections in economics, we believe that a primary goal for business owners who enter into politics is, either directly or via a proxy, monetary gain.

\subsection{Fluidity - A Complex Web of Intra-Elite Rivalry and Changing Alliances}

Hadiz and Robison (2013) argue that it was the very underpinnings of oligarchy in the form of networks of political authority and economic interest that allowed oligarchs to survive the trying times during and after the economic crisis. While attempts were made, reformers with a liberal agenda were never successful in dismantling these networks. This characterization of the ability of the strongest business elite to survive Suharto's fall seems correct. At the same time, the fall of Suharto also meant that the central source of patronage was gone, and that the business elite now had to enhance their networks and adapt them to the new political reality. When Suharto left the scene, a power vacuum and a situation 
characterized by increased competition between several networks of politicians and business owners followed suit (Eklöf, 2002, p. 242).

A direct effect of the fall of Suharto and the ensuing democratization process was a significant increase in fluidity in terms of power and alliances. For example, during Abdurrahman "Gus Dur" Wahid's short period in power, business owners with strong connections to him could get favorable business deals (Eklöf, 2002, p. 242). The continued reliance on personal relations has thus meant that the close ties between business and politicians are as important as ever, but that the outcomes of these alliances are dependent on a shifting political reality.

\subsection{One Thing Worse Than Organized Corruption...}

One direct effect of the downfall of the authoritarian regime in 1998 was that the business elite were no longer under the control of a single power. Whereas the New Order was characterized by Suharto's centralized control, Reformasi would come to be characterized by an intense intra-elite rivalry between different factions (Dick and Mulholland, 2011, p. 74). Basically, it was up to the legal infrastructure to constrain the business elite. Winters (2013) notes that "unfortunately for the nation, there are no longer any strong, independent, or impersonal institutions of law and enforcement to which Indonesia's most powerful actors must submit". A strong and continuous competition between varying interests over state power and access to favorable business deals thus followed. Overall, this process would take much more chaotic forms compared to the process that was in place under the New Order (Hadiz and Robison, 2013). 
When Chatib Basri, at the time Indonesia's minister of finance, was asked about corruption in an interview with BBC, he firmly stated that while corruption may have been comprehensive during Suharto, power has become fragmented after democratization (BBC, 2014). This has in turn resulted in higher transaction costs and a higher level of uncertainty. In Basri's words, "there is something worse than organized corruption and that is unorganized corruption". This argument is supported by research that focuses on the economics of corruption. In their seminal study on corruption, Shleifer and Vishny (1993) argue that the structure of government institutions and the political process are key determinants of the level of corruption. They discuss the case of Russia, where private investors have to negotiate with varying departments, each of which requests a payment in exchange for an approval of a business license or some other form of reward. This results in what is commonly called an "overgrazing" of the common bribe base. In a study on trucking and illegal payments to police, soldiers, and weigh station attendants in Aceh, Olken and Barron (2009) find that decentralized corruption can result in higher bribes compared to a setting in which corruption is more centralized. Finally, Fisman (2010) also discusses what he labels "corruption you can count on" and brings up several examples, including that of Indonesia during and after Suharto's reign.

The decentralized and more chaotic form of corruption that has emerged in the wake of the New Order is central to the study of the economic effects of political connections as it affects the very nature of such connections and the value they bring to those cultivating them. 


\subsection{Decentralization}

One of the most dramatic political and economic changes in Indonesia since the fall of Suharto has been the comprehensive decentralization process that was initiated in 2000 . The rapid pace of this process has resulted in a swift shift in administrative and economic authority from the center to the regents (bupati), mayors (walikota), and local parliaments across the country (Hadiz and Robison, 2013). As a detailed analysis of most of the positive and negative effects of decentralization is beyond the scope of this study, it is sufficient to focus on its effects on business-politics relations. ${ }^{19}$

One important outcome of the decentralization process is that a similar type of competing interests typically found at the center during the New Order is now competing for positions as regents or mayors, including former officials, leading party members, in addition to local business figures and gangsters (Hadiz, 2004, ch. 4). The politicalbureaucratic elites that remained from the New Order period have found new ways to both defend their wealth and to identify and pursue new opportunities for wealth creation at the local level (Hadiz and Robison, 2013). Hadiz (2010, p. 95) notes that local officials in contemporary Indonesia are finding their political positions profitable, as the rent-seeking opportunities at the local level are enhanced as a result of decentralization. Naturally, this development is closely tied to the discussion on organized versus unorganized corruption in the previous section. As power is decentralized, it provides new rent-seeking opportunities for a larger number of agents. However, in addition to this, an important aspect of the decentralized political setting in contemporary Indonesia is the fact that

\footnotetext{
${ }^{19}$ For detailed discussions on the decentralization process and its effects in Indonesia, see Hadiz
} (2010), Holtzappel and Ramstedt (2009), and Lane (2014). 
business-politics relationships are being localized, making it important to not only look at the largest business elite entrepreneurs in terms of total wealth, but also at the local business elite across the country. The sheer size of the country makes this a formidable task, which is why most studies by area specialists and political scientists tend to focus on one or a few localities.

\section{Concluding Remarks}

Previous research on large businesses and the business elite in post-Authoritarian Indonesia has predominantly been carried out by political scientists and area specialists. While their studies contribute significantly to our understanding of how the Indonesian business elite operates, the literature on politically connected firms owned by members of the business elite in contemporary Indonesia still lacks a rigorous empirical treatment of connected firms and conglomerates. Although previous studies, such as Fisman (2001), have helped shed light on the economic effects of connected firms during the New Order, the new political reality in Indonesia has made a similar analysis on firms in contemporary Indonesia more challenging. As a first step to remedy this, this paper has sought to discuss the changing nature of politically connected firms in Indonesia and what economists looking into possible venues for empirical studies on political connections in Indonesia may focus on. This study begins with an overview of the evolution of the patrimonial system in Indonesia.

After discussing the role of the business elite during the economic crisis and the political turmoil in 1998, it sheds light some of the crucial political and institutional features that affect how we analyze and understand firm and firm group effects of political 
ties. Some of the important features of the political and institutional reality in contemporary Indonesia are: the pervasive political activities of members from the business elite; a more fluid political environment in which members of the business elite align themselves with political parties and leaders that they believe will provide them with the best opportunities; a more decentralized patronage system that, combined with the fluid movements in business-politics relations, allow for a higher level of aggregate rent seeking with potential predatory consequences; and decentralization of power and patronclient relationships, a factor that makes it important to complement empirical studies on the largest conglomerates and its owners with studies on the local business elite at, at least, the provincial level across the archipelago.

With an understanding of how business-political relationships function in contemporary Indonesia, it is possible to carry out more comprehensive analyses of the economic effects of political connections as well as the effects of political events that have taken place since the beginning of Reformasi. While outside the scope of this paper, this is a natural next step for economists wanting to contribute to and complement the rich literature on the Indonesian business elite by researchers with a background in political science and area studies. 


\section{Glossary \& Abbreviations}

Benteng program

BPIS

bupati

cukong

Demokrasi Terpimpin

Golkar

HIPMI

Kadin

IMF

Orde Baru

pembanguan

pribumi
Economic policy in place 1950-1957 with the goal of building a strong pribumi business class

Strategic Industries Management Board (Badan Pengelola Industri Strategis), a state agency established in 1989 to supervise some of the largest state enterprises in Indonesia

"Regent", the head of a regency (kabupaten) in Indonesia

"Financial backer", a term used in Indonesia for Chinese businessmen that cooperate closely with those in power, typically the military - originally a Hokkien Chinese term, meaning "master"

Guided Democracy, a political system in Indonesia from the late 1950s to early 1966 when the New Order began - an attempt by president Sukarno to impose political stability through the concentration of power

Partai Golongan Karya (the Party of the Functional Groups) - the ruling party from 1973 to 1999

Himpunan Pengusaha Muda Indonesia (Association of Young Businessmen)

Kamar Dagang dan Industri Indonesia (Indonesian Chamber of Commerce \& Industry)

The International Monetary Fund

The New Order, a term introduced by Suharto to characterize his regime to contrast it with the rule of his predecessor Sukarno

loosely translated as "development" - while the word can be associated with the typical concept of development, it has also been widely used to provide a discourse within which public figures are to operate in Indonesia (for more on the concept of pembangunan see Chalmers (1997, pp. 1-5)

Literally "sons of the land", a term that refers to a population group that shares a similar sociocultural heritage, with its members considered natives of Indonesia 
Reformasi

Sekneg

VOC

walikota

yayasan
"Reform" or "reformation", a movement advocating democratic rights for the Indonesian people that begun in 1998 and which led to changes in Indonesia's political and judiciary institutions

Sekretariat Negara Republik Indonesia (the State Secretariat)

Dutch East India Company (Vereenigde Oostindische Compagnie) - a company established in 1602, making it arguably the world's first multinational corporation, with quasi-governmental powers

mayor of a city ( kota) in Indonesia

Foundation, often for charitable causes - widely used by Suharto during the New Order to funnel large amounts of money 


\section{References}

Anderson, B., 1972. The Idea of Power in Javanese Culture, in Holt, C. (ed.), Culture and Politics in Indonesia. Ithaca, NY: Cornell University Press, 1-69.

Aspinall, E., 2004. Indonesia: Transformation of Civil Society and Democratic Breakthrough. In Alagappa, M. (ed.), Civil Society and Political Change in Asia: Expanding and Contracting Democratic Space. Stanford, CA: Stanford University Press, 61-96.

Aspinall, E., 2005. Opposing Suharto: Compromise, Resistance, and Regime Change in Indonesia. Stanford CA: Stanford University Press.

BBC, 2014. Indonesia Needs Investment from Abroad for Growth. 2 July. <http://www.bbc.com/news/business-28122308>, accessed on October 17, 2014.

Besley, T., Persson, T., Sturm, D.M., 2010. Political Competition, Policy and Growth: Theory and Evidence from the US. Review of Economic Studies 77, 1329-1352.

Booth, A., 1998. The Indonesian Economy in the Nineteenth and Twentieth Centuries: A History of Missed Opportunities. Basingstoke: Macmillan.

Borsuk, R., Chng, N., 2014. Liem Sioe Liong's Salim Group. Singapore: Institute of Southeast Asian Studies.

Brown, R.A., 2006. Indonesian Corporations, Cronyism, and Corruption. Modern Asian Studies 40, 953-992.

Buehler, M., 2010. Decentralisation and Local Democracy in Indonesia: The Marginalisation of the Public Sphere. In Aspinall, E., Mietzner, M. (eds.), Problems of Democratisation in Indonesia: Elections, Institutions, and Society. Singapore: Institute of Southeast Asian Studies, 267-285.

Buehler, M., 2014. Elite Competition and Changing State-Society Relations: Shari'a Policymaking in Indonesia. In Ford, M., Pepinsky, T.P. (eds.), Beyond Oligarchy: Wealth, Power, and Contemporary Indonesian Politics. Ithaca, NY: Cornell Southeast Asia Program Publications, 157-175.

Bueno de Mesquita, B., Morrow, J.D., Siverson, R.M., Smith, A., 2001. Political Competition and Economic Growth. Journal of Democracy 12, 58-72.

Chalmers, I., 1997. Introduction. In Chalmers, I., Hadiz, V., The Politics of Economic Development in Indonesia: Contending Perspectives. London: Routledge, 1-35.

Chehabi, H.E., Linz, J.J., 1998. A Theory of Sultanism 1: A Type of Nondemocratic Rule. In Chehabi, H.E., Linz, J.J. (eds.), Sultanistic Regimes. Baltimore, MD.: John Hopkins University Press, pp. 3-25.

Chua, C., 2009. Capitalist Consolidation, Consolidated Capitalists: Indonesia's Conglomerates between Authoritarianism and Democracy. In Bünte, M., Ufen, A. (eds.), Democratization in Post-Suharto Indonesia. New York, NY: Routledge, pp. 201-225. 
Claessens, S., Djankov, S., Lang, L.H.P, 1999a. Who Controls East Asian Corporations? Policy Research Working Paper 2054. Washington, DC: World Bank.

Claessens, S., Djankov, S., Lang, L.H.P, 1999b. Who Controls East Asian Corporations - And the Implications for Legal Reforms. Public Policy for the Private Sector. Washington DC: World Bank.

Cole, D.C., Slade, B.F., 1998. Why Has Indonesia's Financial Crisis Been So Bad? Bulletin of Indonesian Economic Studies 34, 61-66.

Colmey, J., Liebhold, D., 1999. Suharto Inc. Time Magazine, May 24. <http://edition.cnn.com/ASIANOW/time/asia/magazine/1999/990524/cover 1.html>, accessed on October 17, 2014.

Corsetti, G., Pesenti, P., Roubini, N., 1999. What Caused the Asian Currency and Financial Crisis? Japan and the World Economy 11, 305-373.

Crouch, H., 1979. Patrimonialism and Military Rule in Indonesia. World Politics 31, 571-587.

Dick, H., Mulholland, J., 2011. The State as Marketplace: Slush Funds and Intra-Elite Rivalry. In Aspinall, E., van Klinken, G., The State and Illegality in Indonesia. Leiden: KITLV Press.

Dominguez, J.I,, 1998. The Batista Regime in Cuba. In Chehabi, H.E., Linz, J.J. (eds.), Sultanistic Regimes. Baltimore, MD.: John Hopkins University Press, pp. 113-131.

D’Souza, J., Megginson, W.L., 1999. The Financial and Operating Performance of Privatized Firms during the 1990s. Journal of Finance 54, 1397-1438.

Eklöf, S., 2002. Politics, Business and Democratization in Indonesia. In Gomez, E.T. (ed.), Political Business in East Asia. London: Routledge.

Fisman, R., 2001. Estimating the value of political connections. American Economic Review 91, 1095-1102.

Fisman, R., 2010. Corruption You Can Count On. Wall Street Journal, April 3.

Fisman, R., Miguel, E., 2008. Economic Gangsters: Corruption, Violence, and the Poverty of Nations. Princeton, NJ: Princeton University Press.

Ford, M., Pepinsky, T.P. (eds.), 2014. Beyond Oligarchy: Wealth, Power, and Contemporary Indonesian Politics. Ithaca, NY: Cornell Southeast Asia Program Publications.

Fukuoka, Y., 2012a. Indonesia's 'democratic transition' Revisited: A Clientelist Model of Political Transition. Democratization 20, 991-1013.

Fukuoka, Y., 2012b. Politics, Business and the State in Post-Soeharto Indonesia. Contemporary Southeast Asia 34, 80-100.

Fukuoka, Y., 2013. Oligarchy and Democracy in Post-Suharto Indonesia. Political Studies Review 11, 52-64.

Galasso, V., Nannicini, T., 2011. Competing on Good Politicians. American Political Science Review 105, 79-99. 
Goldstein, M., 1998. The Asian Financial Crisis: Causes, Cures, and Systemic Implications. Washington, D.C.: Institute for International Economics.

Hadiz, V.R., 2010. Localising Power in Post-Authoritarian Indonesia: A Southeast Asia Perspective. Stanford, CA: Stanford University Press.

Hadiz, V.R, Robison, R., 2013. The Political Economy of Oligarchy and the Reorganization of Power in Indonesia. Indonesia 96, 35-57.

Hicks, J., 2012. A False Start? Indonesian Business Associations as Democratic Actors in the Immediate Post-Soeharto Era. Indonesian Studies Working Papers No. 15, The University of Sydney.

Hill, H., 1996. The Indonesian Economy Since 1996: Southeast Asia's Emerging Giant. Cambridge: Cambridge University Press.

Holtzappel, C.J.G., Ramstedt, M., 2009. Decentralization and Regional Autonomy in Indonesia: Implementation and Challenges. Singapore: Institute of Southeast Asian Studies.

Houben, V.J.H., (2002a). The Pre-Modern Economies of the Archipelago, in Dick, H., Houben, V.J.H., Lindblad, J.T., Wie, T.K. (eds.), The Emergence of a National Economy: An Economic History of Indonesia, 1800-2000. Crows Nest NSW, Australia: Allen and Unwin, 35-55.

Houben, V.J.H., (2002b). Java in the $19^{\text {th }}$ Century: Consolidation of a Territorial State, in Dick, H., Houben, V.J.H., Lindblad, J.T., Wie, T.K. (eds.), The Emergence of a National Economy: An Economic History of Indonesia, 1800-2000. Crows Nest NSW, Australia: Allen and Unwin, 56-81.

Johansson, A.C., Feng, X., 2013. The State Advances, the Private Sector Retreats: Firm Effects of China's Great Stimulus Program. Stockholm School of Economics Asia Working Paper Series 2013-25.

Johnson, C., 1998. Survey of Recent Developments. Bulletin of Indonesian Economic Studies 34, 3-60.

Johnson, S., Boone, P., Breach, A., Friedman, E., 2000. Corporate Governance in the Asian Financial Crisis. Journal of Financial Economics 58, 141-186.

Jones, P.E., 2013. The Effect of Political Competition on Democratic Accountability. Political Behavior 35, 481-515.

Justiniarto, A.I., 2011. State-Business Relations in Post-1998 Indonesia: The Role of Kadin. Doctoral thesis, University of Groningen.

Kaminsky, G.L., Reinhart, C.M., 1998. Financial Crises in Asia and Latin America: Then and Now. American Economic Review Papers and Proceedings 88, 444-448.

Kaminsky, G.L., Reinhart, C.M., 1999. The Twin Crises: The Causes of Banking and Balanceof-Payments Problems. American Economic Review 89, 473-500.

Krugman, P., 1998. What Happened to Asia? Unpublished working paper. Cambridge, MA: MIT. 
Lane, M., 2014. Decentralization \& Its Discontents. Singapore: Institute of Southeast Asian Studies.

Lin, Y., Cai, F., Li, Z., 1998. Competition, Policy Burdens, and State-Owned Enterprise Reform. American Economic Review 88, 422-427.

Lin, Y., Tan, G., 1999. Policy Burdens, Accountability, and the Soft Budget Constraint. American Economic Review 89, 426-431.

MacIntyre, A., 1991. Business and Politics in Indonesia. Sydney: Allen \& Unwin.

Mackie, J., 2003. Pre-1997 Sino-Indonesian Conglomerates, Compared with Those of Other ASEAN Countries. In Jomo, K.S., Folk, B.C. (eds.), Ethnic Business. London Routledge, 105-128.

Mackie, J., 2011. Patrimonialism: The New Order and Beyond. In Aspinall, E., Fealy, G. (eds.), Soeharto's New Order and Its Legacy: Essays in Honour of Harold Crouch. Canberra: ANU E Press, 81-96.

Megginson, W., Netter, J., 2001. From State to Market: A Survey of Empirical Studies on Privatization. Journal of Economic Literature 39, 321-389.

Mietzner, M., 2013. Money, Power, and Ideology: Political Parties in Post-Authoritarian Indonesia. Singapore: NUS Press.

Mishkin, F.S., 1999. Lessons from the Asian Crisis. Journal of International Money and Finance 18, 709-723.

Nicholls, D., 1998. The Duvalier Regime in Haiti. In Chehabi, H.E., Linz, J.J. (eds.), Sultanistic Regimes. Baltimore, MD.: John Hopkins University Press, 153-181.

Olken, B.A., Barron, P., 2009. The Simple Economics of Extortion: Evidence from Trucking in Aceh. Journal of Political Economy 117, 417-452.

0’Rourke, K., 2003. Reformasi: The Struggle for Power in Post-Soeharto Indonesia. Crows Nest, NSW: Allen \& Unwin.

Pepinsky, T.B., 2009. Economic Crises and the Breakdown of Authoritarian Regimes: Indonesia and Malaysia in Comparative Perspective. New York, NY: Cambridge University Press.

Pepinsky, T.B., 2012. When Did Reformasi End? Online posting October 12, 2012. <http://tompepinsky.com/2012/10/12/when-did-reformasi-end/>, accessed on October 17, 2014.

Persson, T., Tabellini, G., 2000. Political Economics: Explaining Economic Policy. Cambridge, MA: MIT Press.

Purdey, J., 2006. Anti-Chinese Violence in Indonesia, 1996-1999. Honolulu, HI: University of Hawaii Press.

Radelet, S., Sachs, J., 1998. The East Asian Financial Crisis: Diagnosis, Remedies, Prospects. Brookings Papers on Economic Activity 1, 1-74.

Robison, R., 1986. Indonesia: The Rise of Capital. Sydney: Allen \& Unwin. 
Robison, R., 1988. Authoritarian States, Capital-Owning Classes, and the Politics of Newly Industralized Countries: The Case of Indonesia. World Politics 41, 52-74.

Robison, R., Hadiz, V., 2004. Reorganising Power in Indonesia: The Politics of Oligarchy in an Age of Markets. New York, NY: Routledge.

Rogers, D.L., Rogers, J.H., 2000. Political Competition and State Government Size: Do Tighter Elections Produce Looser Budgets? Public Choice 105, 1-21.

Sato, Y., 2003. Post-Crisis Economic Reform in Indonesia: Policy for Intervening in Ownership in Historical Perspective. IDE Research Paper No. 4.

Schwarz, A., 2004. A Nation in Waiting: Indonesia's Search for Stability. $3^{\text {rd }}$ edition. Singapore: Talisman.

Shleifer, A., Vishny, R.W., 1993. Corruption. Quarterly Journal of Economics 108, 599-617.

Soesastro, H., Basri, M.C., 1998. Survey of Recent Developments. Bulletin of Indonesian Economic Studies 34, 3-54.

The Jakarta Post, 2004. Six Years After, May 1998 Tragedy Still Unresolved. May 13. <http://www.thejakartapost.com/news/2004/05/13/six-years-after-may1998-tragedy-still-unresolved.html>, accessed on October 17, 2014.

The Jakarta Post, 2009. Taking a Closer Look Into Kadin's Economic Road Map. 7 November. <http://www.thejakartapost.com/news/2009/11/07/taking-a-closer-lookkadin039s-economic-road-map.html>, accessed on October 17, 2014.

Thompson, M.R., 1998. The Marcos Regime in the Philippines. In Chehabi, H.E., Linz, J.J. (eds.), Sultanistic Regimes. Baltimore, MD.: John Hopkins University Press, 206230.

Weitz-Shapiro, R., 2008. Choosing Clientelism: Political Competition, Poverty and Social Welfare Policy in Argentina. PhD Dissertation, Columbia University.

Winters, J.A., 1996. Power in Motion: Capital Mobility and the Indonesian State. London: Cornell University Press.

Winters, J.A., 2011. Oligarchy. New York, NY: Cambridge University Press.

Winters, J.A., 2013. Oligarchy and Democracy in Indonesia. Indonesia 96, 11-33. 